AJChE 2020, Vol. 20, No. 2, 165 - 173

\title{
Convective Baking Characteristics and Effective Moisture Diffusivities of Yellow Mealworms
}

\author{
Wei Hon Seah ${ }^{1}$ \\ Alecia Sze Mun Wong ${ }^{1}$ \\ Wei Qin Nie Naik ${ }^{1}$ \\ Chun Mun Tan ${ }^{1}$ \\ Choon Lai Chiang ${ }^{2}$ \\ Ching Lik Hii ${ }^{*}$ \\ 1 Future Food Malaysia, Department of Chemical and Environmental Engineering, Faculty of \\ Science and Engineering, University of Nottingham Malaysia, Jalan Broga, 43500 Semenyih, \\ Selangor Darul Ehsan, Malaysia. \\ ${ }^{2}$ Engineering Foundation, Faculty of Science and Engineering, University of Nottingham Malaysia, \\ Jalan Broga, 43500 Semenyih, Selangor Darul Ehsan, Malaysia. \\ *e-mail: Ching-Lik.Hii@nottingham.edu.my
}

Yellow mealworm is an alternative protein source studied by researchers to provide an alternative supply of protein to meet the growing demands of human consumption. In this research, convective baking of yellow mealworms at $80^{\circ} \mathrm{C}, 100^{\circ} \mathrm{C}$, and $120^{\circ} \mathrm{C}$ was carried out to study the baking kinetics and product quality. Studies showed the typical falling trend of the moisture ratio curves, which are typical for most bioproducts that undergo hot air treatment. Mathematical modelling showed that the Page model gave a good prediction on the baking kinetics with high fitting accuracy $\left(R^{2}>0.99\right)$. Effective diffusivities were determined from $1.66 \times 10^{-11}$ to $2.88 \times 10^{-11} \mathrm{~m}^{2} / \mathrm{s}$ within the temperatures tested. The activation energy was estimated at $15.7 \mathrm{~kJ} / \mathrm{mol}$ based on the Arrhenius equation. The final baked samples appeared darker in color because the browning reaction and reduction in bulk density and product length were observed in the range of 48-54\% and $3.0-16.3 \%$, respectively.

Keywords: Baking, Diffusivity, Mealworm, Modelling, Moisture

\section{INTRODUCTION}

The utilization and consumption of insects as a food source have been practiced by humankind for many years (Ramos-Elorduy 2009). However, not everyone is able to accept this idea as insects are mostly perceived as pests that could carry diseases or could be poisonous and damaging to human health. In sustainable food sources and consumption, entomophagy is an alternative to meet the growing demands for proteins, fats, minerals, vitamins, and carbohydrates, especially to the 820 million populations currently still in hunger (WHO 2019). In addition, the increasing growth of the human population requires a search for an alternative protein source that could be acquired through natural products, especially from underutilized or unexplored sources, e.g., insects. 
Although the consumption of edible insects is gaining more attention and awareness nowadays, it is yet to be accepted widely by many people (Megido et al. 2018). However, yellow mealworm (Tenebrio molitor) is the most widely used and researched as an alternative food for humans in Europe (Verhoeckx et al. 2014). Proximate analyses (dry basis) showed that mealworms contained 33\% fat, $51 \%$ crude protein, and $43 \%$ true protein (Zhao et al. 2016). This particular insect species is a highly sought after candidate as an alternative protein source owing to its high protein content, well-balanced amino acids profile, efficient feed conversion rate, low greenhouse gases emission, low water food print, low land usage, and technology to mass-produce is available (Liu et al. 2020). Elhassan et al (2019) reported sensory properties of mealworms that could be described as nutty, cereal, and umami, including the less intense flavor of vegetables and Maillard reaction products.

The mealworms can be boiled, dried, or fried and applied to food products to enrich their protein content. Besides applying food ingredients for human consumption, mealworms can also be used as a protein source in animal feed such as fish, chickens, and pigs (Henuk, 2017). It was reported that about $25-100 \%$ of soybean meal or fishmeal could be replaced in the animal feed with no adverse effects observed.

To date, studies on the impact of processing (e.g., baking/drying) on mealworms are scarcely reported in published literature, and most of the studies mainly reported on the nutritional aspects of the insects. Studies on the baking kinetics of food products are crucial as it enables a better understanding of the weight changes of the product due to moisture diffusion and evaporation (Papasidero et al. 2015). In addition, evaluation of the baking kinetics enables determining the engineering transport properties (e.g., effective moisture diffusivity), which is crucial in equipment design to improve the process economics and dryer efficiency (Hii et al. 2017). Finally, the development of product quality attributes (e.g., color, bulk density, and shrinkage) during baking can be related to quality control during processing in order to produce final products with consistent final qualities (Ling et al. 2015).

Therefore, studies were carried out with the aim to investigate the baking kinetics and mathematical modeling of yellow mealworms' baking process at different convective oven temperatures $\left(80-120^{\circ} \mathrm{C}\right)$. It would complement the current information and knowledge that has been reported mainly on the nutritional aspects of mealworms. Hence, the objectives of the studies are described as follow:

- To investigate the baking kinetics and effective moisture diffusivities of yellow mealworms in convective hot air.

- To model the baking kinetics using semitheoretical thin layer models.

- To determine the final product quality attributes in terms of color, shrinkage, and bulk density.

\section{MATERIALS AND METHODS}

\section{Sample}

Live yellow mealworms were purchased from an aquarium shop in the Semenyih 
region (Selangor, Malaysia). Feed and soil residues, including dead or injured mealworms, were removed. The remaining mealworms were transferred to a container with a lid having perforated holes and left in the container for 2 days without food supply for the purpose of purging before freezing (Finke 2002). Upon purging, the mealworms were kept in a freezer at $-10^{\circ} \mathrm{C}$ for two more days to completely stop the activity of mealworms (Verhoeckx et al. 2014). The frozen mealworms were then blanched in hot boiling water for 10 minutes. Upon blanching, the mealworms were let cool on a paper towel and stabilize to ambient conditions.

\section{Convective baking}

The treated mealworms were spread thinly on an aluminum tray (about $500 \mathrm{gm}$ sample per tray) and subjected to convective hot air baking (Memmert, Germany). Baking was performed at $80^{\circ} \mathrm{C}$, $100^{\circ} \mathrm{C}$, and $120^{\circ} \mathrm{C}$ for 90 minutes to ensure the mealworms achieved full dryness (no further weight changes). Moisture content was determined based on the oven method (Hii et al. 2009) by placing the mealworm sample in a small metal dish (randomly picked 12 samples) and dried overnight at $105^{\circ} \mathrm{C}$ for 24 hours. Moisture content was determined every 5 minutes interval and expressed on a dry basis, as shown in equation 1.

$$
M(t)=\frac{W_{t}-W_{d}}{W_{d}}
$$

\section{Effective moisture diffusivity $\left(D_{e}\right)$}

Determination of effective moisture diffusivity $\left(D_{e}\right)$ was carried out by using Fick's $2^{\text {nd }}$ law equation (Crank 1975), which represents the thin layer of mealworms as placed on the tray (slab geometry). MR represents the moisture ratio (Law et al. 2010), and the following equations were used.

$$
\begin{gathered}
M R=\frac{8}{\pi^{2}} \sum_{n=1}^{\infty} \frac{1}{(2 n-1)^{2}} \exp \left[-(2 n-1)^{2} \frac{\pi^{2} D_{e} t}{L^{2}}\right] \\
M R=\left(M_{t}-M_{e}\right) /\left(M_{i}-M_{e}\right)
\end{gathered}
$$

By taking $\mathrm{n}=0$ and multiplying both sides of the equation with a natural log, a linear equation as shown below.

$$
\ln M R=\ln \frac{8}{\pi^{2}}-\frac{\pi^{2} D_{e}}{L^{2}} t
$$

A plot of In MR ( $y$-axis) versus $t$ ( $x$-axis) would give a linear graph that enables the determination of the effective moisture diffusivity. In this case, the slope is equaled to $\pi^{2} D_{e} / L^{2}$.

The effective moisture diffusivity values determined were related to the baking temperatures by assuming an Arrhenius temperature dependency relationship (Bualuang et al. 2011).

$$
D_{e}=D_{o} \exp ^{\frac{-E}{R T}}
$$

\section{Mathematical modeling}

Mathematical modelling was conductedusing semi-empirical thin layer models (Table 2). Regression analyses were conducted using the solver tool (MS Excel, USA). The best-fitted model would show the highest $\mathrm{R}^{2}$, the lowest chi-square, and RMSE values (Hii et al. 2009), respectively.

The model with the best fitting to the experimental data was determined by the correlation of determination $\left(R^{2}\right)$, Chi- 
squared $\left(\chi^{2}\right)$, and root mean square error (RMSE).

Table 1. Thin layer drying models

\begin{tabular}{ll}
\multicolumn{1}{c}{ Model } & \multicolumn{1}{c}{ Equation } \\
\hline Henderson- & $M R$ \\
Pabis & $=\operatorname{aexp}(-k t)$ \\
Page & $M R=$ \\
& $\exp \left(-k t^{n}\right)$ \\
Verma et & $\quad M R=$ \\
al. & $a \exp (-k t)+$ \\
& $(1-$ \\
& $a) \exp (-g t)$ \\
\hline
\end{tabular}

$$
\begin{aligned}
& R^{2}=1-\left\{\left[\sum_{i=1}^{N}\left(M R_{\text {pre }, t}-M R_{\text {exp }, t}\right)^{2}\right] /\right. \\
& \left.\left[\sum_{i=1}^{N}\left(\overline{M R}_{\text {pre }, t}-M R_{\text {exp }, t}\right)^{2}\right]\right\} \\
& \chi^{2}=\left[\sum_{i=1}^{N}\left(M R_{\text {exp }, t}-M R_{\text {pre }, t}\right)^{2}\right] /(N-z)
\end{aligned}
$$

$$
R M S E=\left[\left(\frac{1}{N}\right) \sum_{i=1}^{N}\left(M R_{p r e, t}-M R_{\text {exp }, t}\right)^{2}\right]^{1 / 2}
$$

where $\mathrm{N}$ and $\mathrm{z}$ are the number of data and constants in the model, respectively.

The best-fitted model would show the highest $R^{2}$ and the lowest $\chi^{2}$ and RMSE values, respectively (Phahom and Phoungchandang 2018, Klungboonkrong and Phoungchandang 2018, Yaacob et al. 2019)

\section{Product quality}

Colour analyses were conducted according to $\mathrm{CIE} \mathrm{L}^{*}, \mathrm{a}^{*}$, and $\mathrm{b}^{*}$ parameters. The baked samples were spread thinly in a petri dish, and the color sensor (Precision colour meter, China) was pointed at the samples, and care was taken to make sure it was covered fully.

Bulk density was determined by putting the baked worm samples in a $250 \mathrm{ml}$ measuring cylinder. The bulk density was calculated by dividing the mass (M) with the volume $(\mathrm{V})$ using equation 12.

$$
\rho_{b}=\frac{M}{V}
$$

Product shrinkage was measured based on the length of the baked worm using a vernier calliper. The initial and final length after baking were compared. All the above measurements were carried out in triplicates.

\section{RESULTS AND DISCUSSION}

\section{Baking kinetics}

Figure 3 shows the mealworms' moisture ratio curves at baking temperatures of $80^{\circ} \mathrm{C}, 100^{\circ} \mathrm{C}$, and $120^{\circ} \mathrm{C}$, respectively. An exponential reduction trend over time could be observed, which is typical in most bioproducts under convective hot air treatment. It also represents the diffusion of moisture within the product, which could be due to the liquid/vapour diffusion process or a combination of both. Initial and final baking rates (Table 2 ) are recorded in the range of $0.029-0.065 \mathrm{~g}$ water/g ds.hr and $2.7 \times 10^{-4}-3.4 \times 10^{-5} \mathrm{~g}$ water/g ds.hr, respectively. Higher initial baking rates are recorded at a higher temperature range, mainly attributed to the bigger driving force (temperature gradient) between the hot air and the sample that is conducive to heat transfer. The high rate of heat transfer, in turn, results in a greater rate of mass transfer within the inner vicinity of the product and evaporation of moisture to the surrounding. Convective heat transfer is 
expected to be the primary dominating mode of heat transfer as opposed to heat conduction due to the greater heat transfer coefficient, which is highly correlated to the air temperature.

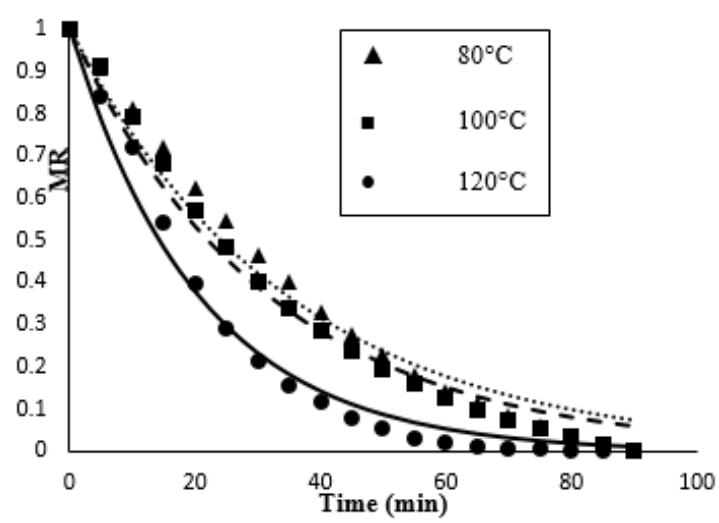

Fig. 1: Variation of moisture ratio against baking time (line graphs represent fitting by Page model)

Table 2. Baking rates

\begin{tabular}{ccc}
\hline $\begin{array}{c}\text { Temperature } \\
\left({ }^{\circ} \mathbf{C}\right)\end{array}$ & $\begin{array}{c}\text { Initial rate } \\
\text { (g water/g } \\
\text { ds.hr) }\end{array}$ & $\begin{array}{c}\text { Final rate } \\
\text { (g water/g } \\
\text { ds.hr) }\end{array}$ \\
\hline 80 & 0.029 & $2.7 \times 10^{-4}$ \\
100 & 0.044 & $2.8 \times 10^{-4}$ \\
120 & 0.065 & $3.4 \times 10^{-5}$ \\
\hline
\end{tabular}

\section{Mathematical modelling}

Mathematical modelling using thin layer models shows that the Page equation could predict the changes in moisture contents for all temperatures throughout the baking period (Figure 1 and Table 3). However, for baking at $120^{\circ} \mathrm{C}$, the Vermal et al. model was equally able to predict as good as the Page model. Nonetheless, fitting analyses showed that the Page equation showed the highest $R^{2}(0.9975-$ 0.9993), lowest Chi-square (0.0001 0.0003), and lowest RMSE (0.0083 - 0.0155) in all the baking experiments. Several studies have reported similar findings

where the Page model can predict at high accuracy for star fruit (Hii and Ogugo 2014), kiwi fruit (Simal et al. 2005), and mango (Akoy 2014).

Table 3. Coefficients and constants of thin layer models

\begin{tabular}{|c|c|c|c|c|}
\hline Model & Constants & $R^{2}$ & $\chi^{2}$ & RMSE \\
\hline \multicolumn{5}{|c|}{$\mathrm{T}=80^{\circ} \mathrm{C}$} \\
\hline \multirow[t]{2}{*}{ Page } & $k=0.0086$ & 0.9975 & 0.0003 & 0.0155 \\
\hline & $\mathrm{n}=1.3244$ & & & \\
\hline Verma & $a=-2.0279$ & 0.9968 & 0.0004 & 0.0175 \\
\hline \multirow[t]{2}{*}{ et al. } & $k=0.0632$ & & & \\
\hline & $g=0.0462$ & & & \\
\hline Hender & $a=1.0748$ & 0.9822 & 0.0019 & 0.0416 \\
\hline son \& & $k=0.0307$ & & & \\
\hline \multicolumn{5}{|l|}{ Pabis } \\
\hline \multicolumn{5}{|c|}{$T=100^{\circ} \mathrm{C}$} \\
\hline \multirow[t]{2}{*}{ Page } & $k=0.0132$ & 0.9987 & 0.0001 & 0.0111 \\
\hline & $\mathrm{n}=1.2408$ & & & \\
\hline Verma & $a=-2.7612$ & 0.9985 & 0.0002 & 0.0120 \\
\hline \multirow[t]{2}{*}{ et al. } & $k=0.0616$ & & & \\
\hline & $g=0.0499$ & & & \\
\hline Hender & $a=1.0672$ & 0.9906 & 0.0010 & 0.0298 \\
\hline son \& & $k=0.0335$ & & & \\
\hline \multicolumn{5}{|l|}{ Pabis } \\
\hline \multicolumn{5}{|c|}{$T=120^{\circ} \mathrm{C}$} \\
\hline \multirow[t]{2}{*}{ Page } & $k=0.0179$ & 0.9993 & 0.0001 & 0.0083 \\
\hline & $\mathrm{n}=1.3088$ & & & \\
\hline Verma & $a=-2.2824$ & 0.9993 & 0.0001 & 0.0083 \\
\hline \multirow[t]{2}{*}{ et al. } & $k=0.1044$ & & & \\
\hline & $g=0.0783$ & & & \\
\hline Hender & $a=1.0662$ & 0.9887 & 0.0012 & 0.0327 \\
\hline son \& & $\mathrm{k}=0.0512$ & & & \\
\hline Pabis & & & & \\
\hline
\end{tabular}

Page model is an improved version of the Newton model (without constant ' $n$ '), and the constant ' $n$ ' acts as a correction term to improve the experimental data's fitting accuracy. The main advantage of applying a semi-theoretical model is the 
ease of application in describing the moisture diffusion process.

\section{Effective moisture diffusivity}

The effective moisture diffusivity values (Table 4) show an increasing trend across increasing baking temperatures. The values are in the order of magnitude, which falls within the range as reported in literatures $\left(10^{-8} \mathrm{~m}^{2} / \mathrm{s}-10^{-14} \mathrm{~m}^{2} / \mathrm{s}\right.$ ) (Law et al. 2010). It can be seen that the effective moisture diffusivity value determined at $120^{\circ} \mathrm{C}$ is at least 1.0 unit higher than that at $100^{\circ} \mathrm{C}$, which could be due to the high rate of evaporation of moisture inside the mealworm as the boiling point of water is $100^{\circ} \mathrm{C}$ at atmospheric pressure (1 atm). It contributes to a faster diffusion rate of moisture in a gaseous state as compared to liquid at the lower temperature.

Table 4. Effective moisture diffusivities

\begin{tabular}{cc}
\hline Temperature $\left({ }^{\circ} \mathbf{C}\right)$ & $\begin{array}{l}\text { Effective } \\
\text { moisture } \\
\text { diffusivity }\left(\mathbf{m}^{2} \mathbf{~} \mathbf{s}\right)\end{array}$ \\
\hline 80 & $1.66 \times 10^{-11}$ \\
100 & $1.83 \times 10^{-11}$ \\
120 & $2.88 \times 10^{-11}$ \\
\hline
\end{tabular}

The relationship between the effective moisture diffusivities can be related to the baking temperatures using the Arrhenius relationship (Chong et al. 2009). It results in equation 12, where the activation energy is calculated at $15.7 \mathrm{~kJ} / \mathrm{mol}$. The activation energy is known as the minimum energy level that needs to be overcome for moisture diffusion to occur (Zogzas et al. 1996).

$$
D_{e}=3.27 \times 10^{-9} \exp ^{-15.7 / R T}
$$

\section{Product quality}

Figure 2 shows the plot of $L^{*}, a^{*}$, and $b^{*}$ colour parameters of the baked worm samples. It can be seen that $L^{*}$ values showed a decreasing trend while $a^{*}$ and $b^{*}$ values showed an increasing trend with temperatures. It showed a tendency for the samples to turn darker, as indicated in the decreasing $L^{*}$ values (from 39.4 to 33.3 ). In addition, there was also a tendency for the samples to become reddish (a* values from 7.3 to 11.6 ) and yellowish ( $b$ * values from 13.1 to 18.2 ) upon baking. These colour changes could be attributed to the browning reaction as the mealworms could undergo the browning process owing to its high protein content. Typical protein contents of the mealworms are reported on a 63-69\% dry basis (Ghaly and Alkoaik 2009).

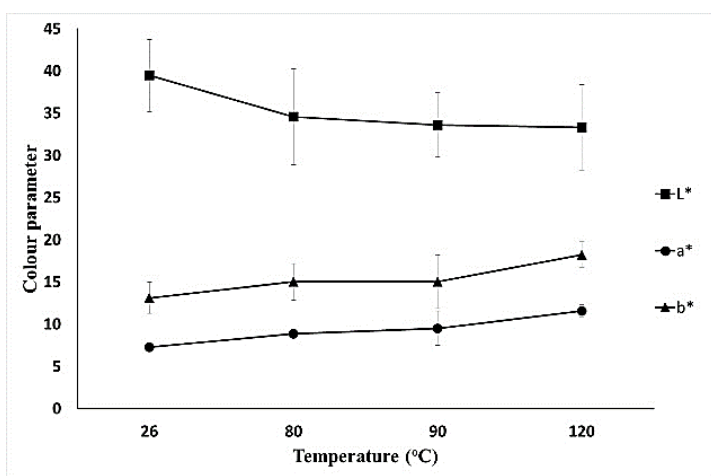

Fig. 2: Variation of colour parameters against temperature (room temperature at $26^{\circ} \mathrm{C}$ indicates raw samples)

Figure 3 shows the plot of bulk density and product length (shrinkage) of the mealworms with temperature. It can be seen that there was a decreasing trend in both measured parameters upon baking.

Bulk densities and length measurements showed a reduction in the 
range of $48-54 \%$ and $3.0-16.3 \%$, respectively. It is expected as moisture was being removed from the samples during baking and resulted in weight reduction and product shrinkage. It was observed that product shrinkage is more significant lengthwise compared to crosswise (e.g., diameter) during baking.

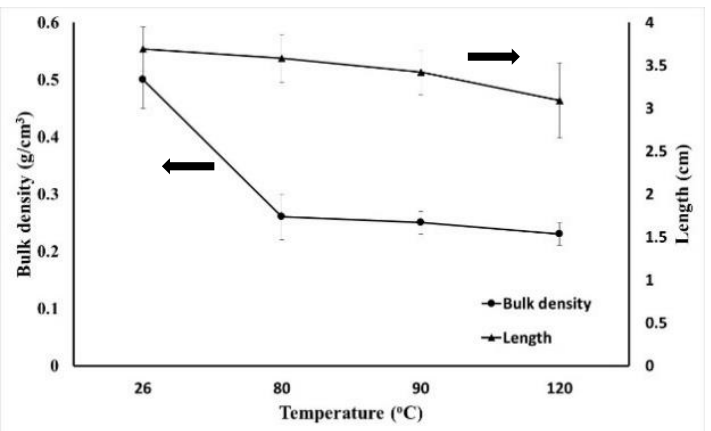

Fig. 3: Variation of bulk density and length against temperature (room temperature at $26^{\circ} \mathrm{C}$ indicates raw samples)

\section{CONCLUSIONS}

The current research investigated convective baking of yellow mealworms inside an oven. Studies showed that the initial rate of baking increased with convective baking temperature due to the greater temperature gradient for heat transfer and subsequently improved the moisture migration process. Modelling showed that Page model predicted well changes in moisture ratios with times $\left(R^{2}=\right.$ $0.9975-0.9993, \chi^{2}=0.0001-0.0003$ and RMSE $=0.0083-0.0155)$ for temperatures ranging from $80^{\circ} \mathrm{C}-120^{\circ} \mathrm{C}$. Effective moisture diffusivities were determined, ranging from $1.66 \times 10^{-11}$ to $2.88 \times 10^{-11}$ $\mathrm{m}^{2} / \mathrm{s}$ with activation energy estimated at $15.7 \mathrm{~kJ} / \mathrm{mol}$ based on the Arrhenius equation. Quality analyses showed colour changes of the final baked samples that were darker due to the browning reaction and reduction in the range of $48-54 \%$ and $3.0-16.3 \%$ were observed in bulk density and length of the samples, respectively.

\section{NOMENCLATURE}

\begin{tabular}{|c|c|c|}
\hline$a, g, k, n$ & • & constants in empirical models \\
\hline$D_{e}$ & & effective moisture diffusivity, $\mathrm{m}^{2} / \mathrm{s}$ \\
\hline$D_{0}$ & $\cdot$ & constant, $\mathrm{m}^{2} / \mathrm{s}$ \\
\hline ds & : & dry solid \\
\hline E & : & activation energy, $\mathrm{kJ}$ \\
\hline $\mathrm{L}$ & : & sample half-thickness, $\mathrm{m}$ \\
\hline$L^{*}$ & : & lightness \\
\hline$a^{*}$ & : & greenness - redness \\
\hline$b^{*}$ & : & blueness - yellowness \\
\hline MR & $:$ & moisture ratio \\
\hline$M R_{\text {pre }}$ & $:$ & predicted moisture ratio \\
\hline$M R_{\exp }$ & $:$ & experimental moisture ratio \\
\hline $\mathrm{M}_{\mathrm{t}}$ & : & $\begin{array}{l}\text { moisture content, g water/ } \\
\text { g ds }\end{array}$ \\
\hline$M_{i}$ & . & $\begin{array}{l}\text { initial moisture content, } \\
\mathrm{g} \text { water/g ds }\end{array}$ \\
\hline$M_{e}$ & : & $\begin{array}{l}\text { equilibrium moisture content, } \\
\text { g water/g ds }\end{array}$ \\
\hline M & : & mass, $g$ \\
\hline $\mathrm{N}$ & : & number of observations \\
\hline $\mathrm{R}^{2}$ & : & coefficient of determination \\
\hline $\mathrm{R}$ & : & gas constant, $8.314 \mathrm{~J} / \mathrm{mol} . \mathrm{K}$ \\
\hline RMSE & : & root mean square error \\
\hline $\mathrm{t}$ & : & time, hr \\
\hline $\mathrm{T}$ & : & absolute temperature, $\mathrm{K}$ \\
\hline V & : & volume, $\mathrm{m}^{3}$ \\
\hline$x^{2}$ & : & chi squared \\
\hline$W_{t}$ & : & mass after time $\mathrm{t}, \mathrm{g}$ \\
\hline$W_{d}$ & & mass of dry solid, $\mathrm{g}$ \\
\hline $\mathrm{z}$ & & number of constants \\
\hline
\end{tabular}




\section{REFERENCES}

1. Akoy, E.O.M. (2014). "Experimental characterization and modeling of thinlayer drying of mango slices," Int Food Res J., 21(5),1911-1917.

2. Bualuang, O., Tirawanichakul, S. and Tirawanichakul, Y. (2011). "Thermophysical properties and mathematical modeling of thin-layer drying kinetics of medium and long grain parboiled rice," ASEAN Journal of Chemical Engineering, 11(2), 22-36.

3. Chong, C.W., Law, C.L., Cloke, M.W., LC Abdullah, LC. Daud, W.R.W. (2009). "Kinetics of mass transfer, colour, total polyphenol and texture change of Manilkara Zapota during convective air drying," ASEAN Journal of Chemical Engineering 9 (1), 47-59.

4. Crank J., (1975). "The mathematics of diffusion." $2^{\text {nd }}$ ed. Oxford: Clarendon Press.

5. Elhassan, M., Wendin, K., Olsson, V., Langton, M. (2019). "Quality Aspects of Insects as Food-Nutritional, Sensory, and Related Concepts," Foods 2019,8(3) ,95.

6. Finke, MD. (2002). "Complete nutrient composition of commercially raised invertebrates used as food for insectivores," Zoo Biol.,21,269-285.

7. Ghaly, A. E., Alkoaik, F. N. (2009). "The Yellow Mealworm as a Novel Source of Protein," Am J Agric Biol Sci, 4(4), 319331.

8. Henuk, Y. L. (2017). "Mealworm: A promising alternative protein source for animal nutrition," J Vet Sci Technol 2017, 8:5 (Suppl), 24.
9. Hii CL, Law CL, Cloke M. (2009). "Modeling using a new thin layer drying model and product quality of cocoa," J. Food Eng, 90(2), 191-198.

10. Hii CL, Ogugo JF. (2014). "Effect of pretreatment on the drying kinetics and product quality of star fruit slices," J. Eng. Sci. Technol., 9(1), 123 - 135.

11. Hii, $C L$, Menon, $A S$, Chiang, $C L$, Sharif, $S$. (2017). "Kinetics of hot air roasting of cocoa nibs and product quality," J Food Process Eng. 2017, 40, e12467.

12. Klungboonkrong $\mathrm{V}$, Phoungchandang S. (2018). "Microwave drying characteristics and qualities of dried Orthosiphon aristatus leaves," Asia Pac J Sci Technol., 23(1), March

13. Law, C.L , Chong, C.H., and Figiel, A. (2010). "Intermittent hot air, dehumidified air, heat pump and convective cum vacuum microwave drying characteristics and models," ASEAN Journal of Chemical Engineering, 10(2), 10-15.

14. Ling, B., Tang, J., Kong, F., Mitcham E. J., Wang, S. (2015). "Kinetics of Food Quality Changes During Thermal Processing: a Review." Food Bioprocess Technol 8, 343-358.

15. Liu, C., Masri, J., Perez, V., Maya, C., Zhao, J. (2020). "Growth Performance and Nutrient Composition of Mealworms (Tenebrio Molitor) Fed on Fresh Plant Materials-Supplemented Diets," Foods 2020, 9, 151.

16. Megido, R.C., Poelaert, C., Ernens, M., Liotta, M., Blecker, C., Danthine, S., Tyteca, E., Haubruge, É., Alabi, T., Bindelle, J., Francis, F. (2018). "Effect of household cooking techniques on the microbiological load and the nutritional 
quality of mealworms (Tenebrio molitor

L. 1758)," Food Res Int., 106,503-508.

17. Papasidero, D., Pierucci S., Manenti F., Piazza L. (2015). "Heat and Mass Transfer in Roast Beef Cooking. Temperature and Weight Loss Prediction," Chem. Eng. Trans., 43, 151156.

18. Phahom, T., Phoungchandang, S. (2018). "Drying characteristics and quality attributes of Thunbergia laurifolia leaves using microwave drying," Asia Pac J Sci Technol. 23(1), March

19. Ramos-Elorduy, J., (2009). "Anthropoentomophagy: Cultures, evolution and sustainability," Entomol. Res. 39,271288.

20. Simal, S., Femenia, A., Garau, M.C., Rosselló, C. (2005). "Use of exponential, Page's and diffusional models to simulate the drying kinetics of kiwi fruit," J. Food Eng., 66(3), 323-328.

21. Verhoeckx, K.C.M., Van Broekhoven, S., Den Hartog-Jager, C.F., Gaspari, M., De Jong, G.A.H., Wichers, H.J., Van Hoffen, E., Houben, G.F., Knulst, AC. (2014). "House dust mite (Der p 10) and crustacean allergic patients may react to food containing yellow mealworm proteins," Food and Chem Toxicol.,65, 364-373.

22. World Health Organization [Internet]. "World hunger is still not going down after three years and obesity is still growing - UN report." [updated 15 July 2019; cited 28 December 2019]. Available from: https://www.who.int/ news-room/detail/15-07-2019-worldhunger-is-still-not-going-down-afterthree-years-and-obesity-is-still-

\section{growing-un-report}

23. Yaacob, M.D., Leong, K.Y., Sathik, M.R.J., Tan, N.F., Ee, C.T., Ong, S.P., Hii, C.L. (2019). "Modelling of osmotic dehydration of kedondong fruit (Spondias dulcis) immersed in natural pineapple juice," Asia Pac J Sci Technol.,24(3),Jul-Sep.

24. Zhao, X., Vázquez-Gutiérrez, J.L., Johansson, D.P., Landberg, R., Langton, M. (2016). "Yellow mealworm protein for food purposes - extraction and functional properties," PLOS ONE 11(2), e0147791.

25. Zogzas, N.P., Maroulis, Z.B., MarinosKouris, D. (1996). "Moisture diffusivity data compilation in foodstuffs," Dry Technol., 14, 2225-2253. 